\title{
Consumer Purchase Decision in Instagram Stores: The Role of Consumer Trust
}

\author{
Jasmine W. S. Che \\ Hong Kong Baptist University \\ chejasmine930@gmail.com
}

\author{
Christy M. K. Cheung \\ Hong Kong Baptist University \\ ccheung@hkbu.edu.hk
}

\author{
Dimple R. Thadani \\ The University of Nottingham \\ Ningbo China \\ dimple.thadani@nottingham.edu.cn
}

\begin{abstract}
Instagram, a prominent social networking site, has become a popular online shopping platform among young people. In this study, we have attempted to understand what drives people to purchase in virtual stores on Instagram. Specifically, we built upon the integrative framework of trust and identified three groups of factors explaining consumer trust in Instagram stores: trustworthiness of Instagram stores (i.e., perceived benevolence, perceived integrity, and perceived competence), propensity to trust, and external environment (i.e., Key Opinion Leader (KOL) endorsement and peer customer endorsement). These factors are expected to influence consumer trust in Instagram stores, and trust in turn determines consumer intention to purchase. The model was empirically tested with 157 Instagram users. Perceived benevolence, perceived integrity, and $\mathrm{KOL}$ endorsement were found to be significant factors affecting consumer trust in Instagram stores, and trust was found to have a strong relationship with consumer purchase intention. The results of this study are expected to advance the trust literature in the context of social commerce and to offer practical guidelines to Instagram storeowners.
\end{abstract}

\section{Introduction}

The popularity of online shopping along with the wide adoption of social networking sites (SNSs) have recently given rise to a new e-commerce paradigm called social commerce (s-commerce). S-commerce is considered a subset of e-commerce that uses SNSs to facilitate social interactions between consumers and vendors and thus promotes the buying and selling of products and services [1-3].

Instagram has recently become the most popular s-commerce site among young people. By September 2015, the number of active monthly Instagram users had reached 400 million, accounting for $20 \%$ of all internet users [4]. Among these active users, over $40 \%$ were young people aged below 24 [5]. Instagram had an average order value of US\$65 per order, while Facebook had only US\$55 per order [6]. Furthermore, Instagram provides brands with 25\% more engagement than other SNSs [7].

In recent years, increasing numbers of people have opened virtual stores on Instagram. Doing so is simple: users open an account, post sample pictures of products and descriptions, and encourage their followers to shop online. Consumers usually show interest in the products they like by leaving messages on the posts or by contacting the storeowner using messaging apps, such as WeChat, WhatsApp, or Line. Payment is made through PayPal or other traditional methods. Selling products in a virtual store on Instagram represents a new shopping mode for most consumers, and consumer trust is a critical issue in consumer purchase decision on Instagram.

Prior studies have indicated that building consumer trust is a key antecedent of online purchasing $[8,9]$. Because online transactions are not done face-to-face, buyers usually require trustworthiness and useful information to better understand stores and products [10]. However, the extant literature focuses mainly on consumer trust in the context of e-commerce [11]. With the growing popularity of s-commerce, more attention should be paid to how trust could affect online purchasing in such a highly interactive online business environment (i.e., SNSs). In e-commerce, consumer trust is mainly determined by the trustworthiness of online stores (e.g. integrity, competence, benevolence) [12]. Consumers may evaluate the trustworthiness of companies in e-commerce through direct online shopping experiences. However, in the s-commerce context, many consumers attempt to gather more product-related information before they actually buy [13]. Specifically, customers can derive productrelated information from actual buyers and from other SNS users. Thus, understanding the role of consumer trust in the s-commerce context has 
significant meaning for understanding the contemporary model of online purchasing.

Accordingly, this study aims to develop a research model explaining consumer purchase decision in Instagram stores. We build upon the integrative framework of trust [14] and identify three groups of factors: trustworthiness of Instagram stores (i.e., perceived benevolence, perceived integrity, and perceived competence), propensity to trust, and external environment (i.e., Key Opinion Leader (KOL) endorsement and peer customer endorsement). These factors are expected to influence consumer trust in Instagram stores, and trust in turn determines consumer intention to purchase.

We believe that this study makes important theoretical and practical contributions. On the theoretical side, we extend and empirically validate the integrative model of consumer trust in the context of Instagram, thus enriching the trust literature in the context of s-commerce. On the practical side, we identify the key elements for consumer trust in Instagram shopping. We believe that the findings will provide valuable insights for virtual storeowners.

This paper is organized as follows. In the next section, we provide a review of the previous literature on consumer trust. We then introduce the research model and hypotheses. Later, we describe the research methodology and report the findings. Finally, we conclude our paper by discussing implications for both research and practice.

\section{Literature Review}

Trust is a vital concept in a business relationship. This concept has been examined in various contexts, including bargaining [15], industrial buyer-seller relationships [16], distribution channels [17], partner cooperation in strategic alliances [18], and market research [19]. With the electronic commerce boom in the early 2000s, the concept of consumer trust in the online environment has received a great deal of attention from IS researchers [e.g., 20, 21, 22]. Cheung and Lee [14] proposed an integrative framework explaining consumer trust in online shopping built upon Lewicki and Bunker's [23] classification of trust research with three major theoretical perspectives: the views of social psychologists, the views of personality theorists, and the views of sociologists and economists.

\subsection{The views of social psychologists}

Social psychologists consider trust at the interpersonal and group levels. They define trust as an expectation about the behavior of others in transactions. This perspective focuses on how contextual factors enhance or inhibit trust development or maintenance [23]. Mayer and Schoorman [24] identified the three most frequently cited attributes of trustworthiness: competence, benevolence, and integrity. These three attributes have also been widely used in the context of electronic commerce [e.g., 10, 20, 25].

\subsection{The views of psychologists}

Personality theorists view trust as a belief, expectancy, or feeling that is deeply rooted in the personality [26]. They focus on the specific developmental and social contextual factors that shape the readiness of trust. In other words, they believe that people with different developmental experiences, personality types, and cultural backgrounds vary in their formation of trust. Propensity to trust is a frequently examined concept in the electronic commerce context [e.g., 14, 22].

\subsection{The views of sociologists and economists}

Sociologists and economists investigate the issue of trust in terms of institutional mechanisms. In other words, individuals must generalize their trust to large organizations made up of individuals with whom they have low familiarity, low interdependence, and low continuity of interaction. They focus on how institutions and incentives are created to reduce anxiety and uncertainty associated with transactions among relative strangers [27]. The institutional mechanisms have been empirically tested in the electronic commerce context [e.g., 28, 29, 30].

\section{Research Model and Hypothesis}

Consumer purchasing in Instagram stores is a relatively new phenomenon. To the best of our knowledge, there is no empirical study that uses a theoretical framework to examine the factors driving consumer purchase intention in Instagram stores. This mode of shopping represents a new experience for most consumers; thus, we expect that consumer trust is a key driver of consumer purchase decision.

In this study, we build on Lee and Turban's [22] definition of trust and define consumer trust in Instagram stores as the willingness of a consumer to be vulnerable to the actions of an Instagram store based on the expectation that the storeowner will behave in certain agreeable ways irrespective of the ability of the consumers to monitor or control them. 
Furthermore, we build upon the integrative trust framework [14] and propose three major types of factors associated with the formation of consumer trust in Instagram stores.

Figure 1 depicts our research model. Consumer trust is a key factor in determining consumer purchase decision. Drawing from the social psychological perspective, the perceived trustworthiness of Instagram stores (i.e., perceived benevolence, perceived integrity, and perceived competence) is hypothesized as one of the determinants of consumer trust in an Instagram store. The view of personality theorists suggests that the propensity of trust is associated with consumer trust in an Instagram store. Finally, the sociological viewpoint highlights that factors related to the external environment (i.e., key opinion leader endorsement and peer customer endorsement) are important to consumer trust in an Instagram store.

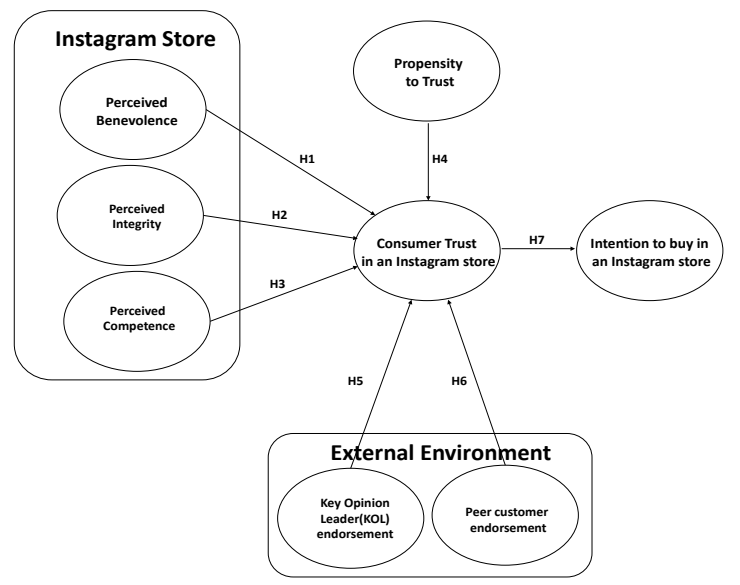

Figure 1. Research model

\subsection{Perceived trustworthiness}

The social psychological perspective emphasizes interpersonal trust and directs us to focus on the relationship between consumers and Instagram storeowners. Because of the lack of physical presence and the newness of this mode of shopping, most consumers do not know the Instagram stores well enough to buy products from them. In other words, consumers do not know which Instagram stores are trustworthy. In line with the potential threats consumers perceive about shopping in Instagram stores, we propose that Instagram storeowners should build up their trustworthiness in three key areas: (1) perceived benevolence, (2) perceived integrity, and (3) perceived competence.
3.1.1. Perceived benevolence. The concept of perceived benevolence refers to the perception that the trustee is doing something good for the trustors [24]. One important characteristic of Instagram stores is that they are usually owned by a small-scale business or a one-person business. The interaction between consumers and Instagram stores is closer: consumers can easily observe how storeowners interact with other consumers and thus form perceptions of the benevolence of the virtual stores. Thus, we expect that when consumers find that Instagram storeowners provide care and good service to their customers, they are more likely to develop trust in their Instagram stores.

Hypothesis 1: The perceived benevolence of an Instagram store is positively related to consumer trust in an Instagram store.

3.1.2. Perceived integrity. The concept of perceived integrity refers to the trustors' perceptions of the honesty of the trustee [24]. One of the major challenges of Instagram stores is that Instagram is not a formal online marketplace. Unlike Taobao or other well-established third-party online marketplaces, Instagram was not originally built for commerce. When consumers show interest in the products shown in a virtual store on Instagram, they contact the storeowner directly and arrange payment through other channels or by traditional methods. The products are delivered through the mail or by physical pick-up in certain locations. In other words, consumers cannot change their mind after they have paid, and they have to arrange product delivery with the virtual storeowners. Thus, when consumers find that Instagram stores show consistent actions and a fair buying-selling process, they are likely to form trust toward these stores.

Hypothesis 2: The perceived integrity of an Instagram store is positively related to consumer trust in an Instagram store.

3.1.3. Perceived competence. The concept of perceived competence is related to the ability of the trustee [24]. There are many virtual stores on Instagram, most of which sell similar products. Accessories, clothes, and cosmetics are the most popular products sold on Instagram stores. As Instagram is a photo-driven platform, the ability to display products with high-quality photos is the most important way to draw consumers' attention. In addition, if storeowners are able to demonstrate knowledge about their products, consumers are more likely to form trust in them. For instance, some 
storeowners provide their consumers with additional information about their products on their Facebook pages or blogs.

Hypothesis 3: The perceived competence of an Instagram store is positively related to consumer trust in an Instagram store.

\subsection{Propensity to Trust}

The psychological perspective focuses on personality traits. Propensity to trust refers to the general propensity to be willing to depend on others [24]. This disposition of trust is stable over time and across situations. Thus, we expect that it should also play a role in explaining consumer trust in Instagram stores. We expect that a person with a higher propensity to trust is more likely to trust an Instagram store.

Hypothesis 4: Propensity to trust is positively related to consumer trust in an Instagram store.

\subsection{External Environment}

Stewart [31] adapted theories from sociology and marketing and suggested that trust can be transferred. Specifically, trust can be transferred from trusted individuals or trusted groups. In the context of Instagram stores, consumers are not able to check the products before purchasing. They may have to rely on other parties to evaluate the Instagram stores. Therefore, we expect that endorsements from other parties affect consumer trust in Instagram stores. In the Instagram environment, there are two major parties, the key opinion leader (KOL) and other consumers, that are visible to consumers.

3.3.1. KOL endorsement. KOL refers to a consumer who provides information and leadership to followers in making their consumption decisions [32]. KOLs are considered experts in specific areas, and their followers trust their recommendations [33]. The perceived effectiveness of KOL endorsement is the degree to which a KOL is perceived to provide trustworthy and useful information that guides consumption decisions. Indeed, one important characteristic of Instagram is that it is built on an infrastructure of hashtags and tagging, which enables users to accumulate a large number of loyal followers, giving rise to KOLs. These KOLs have established their authority on niche products and are able to influence followers' consumption choices. In the absence of direct information regarding Instagram stores' reputation, consumers rely on endorsements from KOLs, whose recommendations are valued.
According to attribution theory [34], a trustor (i.e., a potential customer) could transfer his/her trust in an associated entity (i.e., a KOL) to a trustee (i.e., an Instagram store). We expect that the higher the perceived effectiveness of a KOL's endorsement is, the higher the trust formed toward the Instagram store. In that sense, if Instagram storeowners are able to get these KOLs to recommend their products, consumers are likely to form trust toward the stores.

Hypothesis 5: The perceived effectiveness of a KOL's endorsement is positively related to consumer trust in an Instagram store.

3.3.2. Peer customer endorsement. Peer customer endorsement refers to positive recommendations made by existing customers to potential customers [35]. In the context of e-commerce, researchers have found that consumers tend to exhibit more trust toward those with similar characteristics to them [10]. In that sense, peer customer endorsement is an important source of trust evaluation [35]. One challenge of Instagram stores is that consumers are not able to check the products before purchasing; they have to rely on third parties to evaluate the stores. Potential customers tend to perceive existing customers with similar characteristics and values in a positive light [36, 37]. Thus, we expect that the higher the perceived effectiveness of peer customer endorsement is, the higher the trust formed toward the Instagram stores.

Hypothesis 6: The perceived effectiveness of peer customer endorsement is positively related to consumer trust in an Instagram store.

\subsection{Consumer Purchase Decision}

Trust is a vital concept for online purchasing because it can help ease consumers' uncertainties and reduce the risks associated with buying from Webbased vendors [12]. Thus, building up trust-related behavior is the initial step for web vendors and consumers. Previous studies have shown that when consumers develop trust in an Internet store, they are more willing to share information, make purchases, and interact with others [10]. Similarly, we expect that consumer trust in an Instagram store influence purchase intention.

Hypothesis 7: Trust in an Instagram store is positively related to consumer intention to purchase. 


\section{Study Design and Method}

\subsection{Data Collection}

Given the predominantly Internet-savvy target audience of Instagram users, we used an online survey for data collection. We invited students at a local university to participate in an online survey because the most active age group among Instagram users is between 16 and 24 years of age [5, 38]. An invitation message with a URL to the online survey was sent by email and posted on a number of platforms, including Facebook groups. A screening question was asked to ensure that the respondents had prior experience in visiting Instagram stores.

\subsection{Measures}

All the measurement items for this study were adopted from valid scales with modifications made to fit the current context (See appendix A). We assessed all the constructs using perceptual scales with responses measured on a seven-point Likert scale (7 = strongly agree; 1 = strongly disagree). To ensure construct validity and reliability, we used multiple items to assess each construct.

\subsection{Sample Profile}

A total of 205 responses were collected. 26 were screened out because of a lack of Instagram store visiting experience and 20 were deleted because of incompletion, yielding a sample of 157 for subsequent statistical analysis. Of the 157 respondents, 66 were male and 91 were female, which is consistent with the gender distribution of Instagram users, of whom over $60 \%$ were females in 2014 [38]. Table 1 summarizes the descriptive statistics for the sample.

Table 1. Demographic profile of the respondents

\begin{tabular}{|l|l|l|}
\hline Demographic Characteristics & No. & $\%$ \\
\hline $\begin{array}{l}\text { Previous Instagram store } \\
\text { visiting experience(s) }\end{array}$ & & \\
\hline Yes & 157 & 85.8 \\
\hline No & 26 & 14.2 \\
\hline Gender & & \\
\hline Male & 66 & 42.0 \\
\hline Female & 91 & 58.0 \\
\hline Age & & \\
\hline 18 or under & 1 & 0.6 \\
\hline $18-25$ & 150 & 95.5 \\
\hline $25-30$ & 6 & 3.9 \\
\hline
\end{tabular}

\begin{tabular}{|l|l|l|}
\hline $\begin{array}{l}\text { Year of experience of using } \\
\text { Instagram }\end{array}$ & & \\
\hline Less than 1 year & 10 & 6.4 \\
\hline 1-2 years & 30 & 19.1 \\
\hline 2-3 years & 48 & 30.6 \\
\hline More than 3 years & 69 & 43.9 \\
\hline $\begin{array}{l}\text { Frequency of using } \\
\text { Instagram per day }\end{array}$ & & \\
\hline 0-1 time & 19 & 12.1 \\
\hline 1-2 times & 10 & 6.4 \\
\hline 2-3 times & 34 & 21.7 \\
\hline 3-4 times & 33 & 21.0 \\
\hline$>4$ times & 61 & 38.9 \\
\hline $\begin{array}{l}\text { Previous Instagram } \\
\text { purchase experience(s) }\end{array}$ & & \\
\hline Yes & 92 & 58.6 \\
\hline$\quad$ No & 64 & 41.4 \\
\hline Purpose of using Instagram & & \\
\hline 1. For entertainment & 138 & \\
\hline 2. To interact with friends & 99 & \\
\hline 3. To obtain information & 76 & \\
\hline 4. To share status & 54 & \\
\hline
\end{tabular}

\section{Results}

The measurement model and structural model were validated using the partial least squares (PLS) technique, which employs a component-based approach to estimation and imposes minimal restrictions on data distribution. PLS is preferred in this study over other analytical techniques because it is exploratory in nature. Following the two-step analytical approach, we first performed the psychometric assessment of the measurement model, followed by an evaluation of the structural model. This approach ensures that the conclusions of the structural model are drawn from a set of measures with desirable psychometric properties [39, 40].

\subsection{The Measurement Model}

5.1.1. Convergent validity. Convergent validity indicates the extent to which the items of a scale that are theoretically related to each other should correlate highly. Convergent validity is assessed using three criteria: (1) the composite reliability (CR) should be at least 0.70 [41], (2) the average variance extracted [42] should be at least 0.50 [43], and (3) all item loadings should be greater than $0.70[39,43]$. As illustrated in Table 2, all latent constructs exceed the recommended thresholds, with $\mathrm{CR}$ values ranging from 0.86 to 0.96 , AVE values ranging from 0.69 to 0.92 , and item loadings higher than 0.70 , thus supporting convergent validity. 
Table 2. Psychometric properties of the measures

\begin{tabular}{|c|c|c|c|c|}
\hline Construct & Item & Loading & $\begin{array}{c}\text { t- } \\
\text { value }\end{array}$ & Mean \\
\hline \multirow{4}{*}{$\begin{array}{l}\text { Purchase } \\
\text { Intention (PIT) } \\
C R=0.93 \\
\text { AVE }=0.76\end{array}$} & $\mathrm{BI} 1$ & 0.87 & 37.1 & 4.28 \\
\hline & $\mathrm{BI} 2$ & 0.76 & 12.7 & 4.39 \\
\hline & $\mathrm{BI3}$ & 0.91 & 60.1 & 4.44 \\
\hline & $\mathrm{Bl} 4$ & 0.90 & 55.6 & 4.46 \\
\hline \multirow{6}{*}{$\begin{array}{l}\text { Peer Customer } \\
\text { Endorsement } \\
\text { (PE) } \\
C R=0.93 \\
A V E=0.69\end{array}$} & CE1 & 0.81 & 20.2 & 4.68 \\
\hline & CE2 & 0.77 & 17.5 & 4.80 \\
\hline & CE3 & 0.82 & 20.3 & 4.66 \\
\hline & CE4 & 0.86 & 30.9 & 4.94 \\
\hline & CE5 & 0.87 & 29.0 & 4.89 \\
\hline & CE6 & 0.84 & 21.1 & 4.85 \\
\hline \multirow{4}{*}{$\begin{array}{l}\text { Key Opinion } \\
\text { Leader } \\
\text { Endorsement } \\
\text { (KOL) } \\
\text { CR=0.91 } \\
\text { AVE=0.71 }\end{array}$} & UR1 & 0.83 & 20.0 & 4.77 \\
\hline & UR2 & 0.84 & 26.6 & 4.67 \\
\hline & UR3 & 0.87 & 27.9 & 4.50 \\
\hline & UR4 & 0.82 & 25.0 & 4.54 \\
\hline \multirow{2}{*}{$\begin{array}{l}\text { Perceived } \\
\text { Benevolence(PB) } \\
C R=0.86 \\
\text { AVE }=0.79\end{array}$} & PB1 & 0.94 & 113.1 & 4.48 \\
\hline & PB2 & 0.84 & 23.2 & 4.73 \\
\hline \multirow{3}{*}{$\begin{array}{l}\text { Perceived } \\
\text { Competence (PC) } \\
\text { CR }=0.90 \\
\text { AVE }=0.75\end{array}$} & PC1 & 0.85 & 22.3 & 4.78 \\
\hline & PC2 & 0.91 & 55.2 & 4.52 \\
\hline & PC3 & 0.85 & 29.0 & 4.47 \\
\hline \multirow{3}{*}{$\begin{array}{l}\text { Perceived } \\
\text { Integrity (PI) } \\
C R=0.92 \\
\text { AVE }=0.80\end{array}$} & PI1 & 0.86 & 33.6 & 4.48 \\
\hline & $\mathrm{PI} 2$ & 0.91 & 54.2 & 4.57 \\
\hline & $\mathrm{PI3}$ & 0.92 & 54.0 & 4.76 \\
\hline \multirow{2}{*}{$\begin{array}{l}\text { Propensity to } \\
\text { Trust [44] } \\
\text { CR }=0.96 \\
\text { AVE }=0.92\end{array}$} & PT1 & 0.96 & 127.4 & 4.40 \\
\hline & PT2 & 0.96 & 96.6 & 4.48 \\
\hline \multirow{5}{*}{$\begin{array}{l}\text { Consumer Trust } \\
\text { (TR) } \\
C R=0.93 \\
\text { AVE }=0.74\end{array}$} & TR1 & 0.86 & 39.5 & 4.30 \\
\hline & TR2 & 0.88 & 42.3 & 4.13 \\
\hline & TR3 & 0.86 & 34.8 & 3.90 \\
\hline & TR4 & 0.83 & 24.7 & 4.52 \\
\hline & TR5 & 0.86 & 35.7 & 4.17 \\
\hline
\end{tabular}

5.1.2. Discriminant validity. Discriminant validity is the extent to which a measurement is not a reflection of some other variable. It examines the correlation between the measure of interest and the measures of other constructs [43]. Discriminant validity can be verified when the square root of the average variance extracted for a construct is higher than its correlations with all other constructs [43]. As illustrated in Table 3 , the square roots of all the AVEs were larger than all of the cross-correlations, suggesting adequate discriminant validity.
Table 3. Inter-construct correlation matrix

\begin{tabular}{|c|c|c|c|c|c|c|c|c|}
\hline & PIT & $\mathrm{CE}$ & KOL & PB & $\mathrm{PC}$ & $\mathrm{PI}$ & PT & TR \\
\hline PIT & 0.87 & & & & & & & \\
\hline CE & 0.50 & 0.83 & & & & & & \\
\hline KOL & 0.52 & 0.61 & 0.84 & & & & & \\
\hline PB & 0.54 & 0.61 & 0.58 & 0.89 & & & & \\
\hline PC & 0.44 & 0.66 & 0.56 & 0.73 & 0.87 & & & \\
\hline PI & 0.57 & 0.65 & 0.64 & 0.81 & 0.73 & 0.90 & & \\
\hline PT & 0.44 & 0.46 & 0.54 & 0.60 & 0.58 & 0.60 & 0.96 & \\
\hline TR & 0.68 & 0.56 & 0.61 & 0.69 & 0.56 & 0.68 & 0.52 & 0.86 \\
\hline \multicolumn{9}{|c|}{$\begin{array}{l}\text { Note. Items on the diagonal represent the square roots of } \\
\text { AVEs. } \\
\text { Key: PIT: Purchase Intention; CE:Peer customer endorsement; } \\
\text { KOL: Key opinion leader endorsement; PB: perceived } \\
\text { benevolence; PC: Perceived competence; PI: Perceved } \\
\text { integrity; PT= propensity to trust; TR= Consumer trust }\end{array}$} \\
\hline
\end{tabular}

5.1.3. Common Method Variance. Because the data were collected from a single source (i.e., a self-report questionnaire), there is the potential for the occurrence of common method bias [45]. Harman's one-factor test $[46,47]$ was performed to determine the extent of the method variance in the current data. All the variables in the questionnaire were subjected to an exploratory factor analysis (principal components factor analysis with no rotation). According to this test, if a single factor emerges from the factor analysis or one "general" factor accounts for most of the variance ( $>50 \%$ ), common method variance is deemed to be present. The results suggest that no single factor explained more than $50 \%$ of the variance, indicating that the common method effects are not a likely contaminant of the results observed in this investigation.

\subsection{The Structural Model}

Using SmartPLS (Version 3.0), the structural model and hypotheses were assessed by examining path coefficients, their significance levels, and their associated $t$-values [41]. The significance of all the paths in the model was assessed via 500 bootstrap runs. The results support four of the hypotheses (see Figure 2).

Our model explains $57.0 \%$ of the variance in consumer trust in Instagram stores and $47.0 \%$ of the variance in intention to shop in Instagram stores. Consumer trust has a significant effect on purchase intention ( $\beta=0.69, t=16.13)$. Surprisingly, not all the structural paths are statistically significant in the proposed research model. Among the six factors affecting consumer trust, only perceived benevolence $(\beta=0.36, t=3.77)$, perceived integrity $(\beta=0.21, t=$ $2.24)$, and key opinion leader endorsement ( $\beta=0.23$, 
$t=2.94$ ) were found to be significant, providing support for H1a, H1b, and H1e.

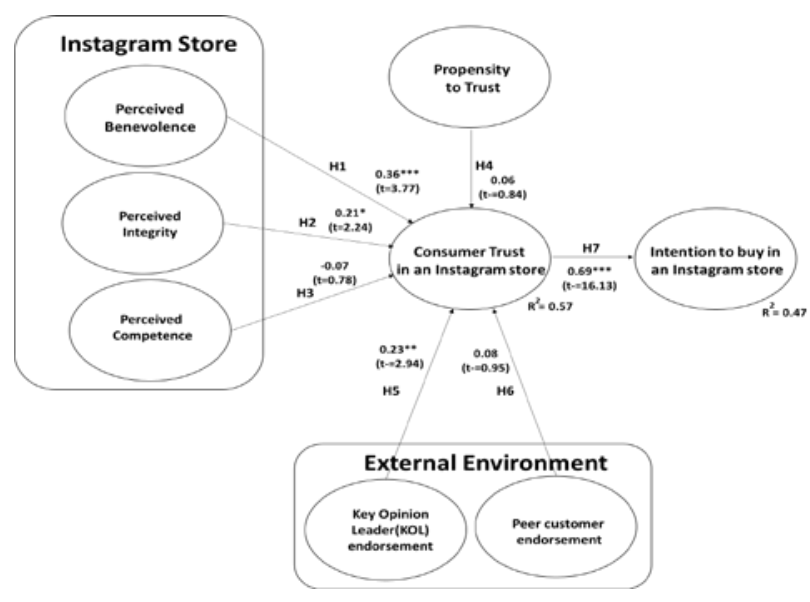

Figure 2. Results

\section{Discussion}

Motivated by the need to better understand consumer purchase decision in Instagram stores, we synthesized the three key theoretical perspectives of trust and developed an integrative model explaining consumer purchase decision in Instagram stores. Three groups of factors are identified in the study: the trustworthiness of Instagram stores (i.e., perceived benevolence, perceived integrity, and perceived competence), propensity to trust, and external environment (i.e., Key Opinion Leader (KOL) endorsement and peer customer endorsement). These three groups of factors are hypothesized to influence consumer trust in Instagram stores, and trust in turn determines consumer intention to purchase.

Empirical testing of our research model on 157 active Instagram users found that consumer trust has a significant effect on purchase intention in Instagram stores. This supports the theoretical argument that building trust is a vital element for eliminating uncertainties and triggering consumer purchase intention. In addition, our results show that the perceived benevolence and perceived integrity of Instagram stores and key opinion leader (KOL) endorsement are significant factors explaining consumer trust in Instagram stores. However, the effects of perceived competence of Instagram stores, propensity to trust, and customer endorsement are not found to be significant. This paper contributes to our conceptual and empirical understanding of consumer purchase decision in Instagram stores. The implications of this study are noteworthy for both researchers and practitioners.

\subsection{Implications for Researchers}

This is one of the few studies that contribute a holistic review of the underlying factors affecting consumer trust in the context of Instagram. The diverse views of trust illustrate the complementarity of the three streams of trust literature. In this study, the proposed model explains $57 \%$ of the variance of consumer trust in Instagram stores. The results demonstrate that an integration of cross-disciplinary studies is important to advance our theoretical understanding of consumer trust in social commerce. Furthermore, the integrative model has been validated in the context of social commerce in general and in Instagram stores in particular.

In addition to empirically establishing the relationship in the integrative model, this study has introduced factors specific to social commerce. KOL endorsement, a newly proposed factor, exhibits a strong relationship with consumer trust. While customer endorsement is a key factor in explaining trust in the e-commerce context, it is interesting that it is less important in the social commerce environment.

\subsection{Implications for Practice}

Consumer trust remains an important currency in the online environment. To encourage consumers to purchase in virtual stores on Instagram, Instagram storeowners should spend resources to build consumer trust. Internally, they should pay more attention to the perceived benevolence and perceived integrity of their stores. In other words, they should demonstrate care and goodwill to their customers (e.g., through campaigns) and keep their promises to their customers (e.g., delivery times and payment arrangements). Externally, Instagram storeowners should line up with KOLs. Specifically, they should launch campaigns with KOLs or invite KOLs to try their products and provide reviews and comments.

\section{Limitations and Directions for Future Research}

When interpreting the results, a number of limitations should be acknowledged, which may lead to several avenues for further research. This research adopts the integrative model of trust with a focus on three key theoretical perspectives: social psychologists, psychologists, and sociologists. One possible extension of this model is to incorporate technology-specific variables to provide a more accurate depiction of the technologies examined. For 
instance, the quality of photos and videos are core components of Instagram, and the current model does not capture how these features influence the formation of trust.

Care must be taken when extrapolating the findings of this study to other cultures and technologies. The respondents were recruited predominantly from Asia, which has stronger collectivism. Our use of a single sample of respondents might have introduced a bias that lessens the generalizability of our findings. Thus, future researchers should test the theoretical model with new datasets obtained from respondents from different cultures to increase its generalizability.

As this study investigates one of the most popular social platforms, Instagram, its results may be generalizable only to Instagram users. Future research should replicate and validate the theoretical model for other social commerce platforms to improve its generalizability. Finally, the data were collected in a cross-sectional research setting. Future studies should incorporate the longitudinal research design to demonstrate how trust influences purchase intention, which in turn influences purchase behavior.

\section{References}

[1] Kim, S. and H. Park, "Effects of various char-acteristics of social commerce (s-commerce)on consumers turst and trust performance," International Journal of Information Management, vol. 33, pp. 318-332, 2013.

[2] Hajli, N., "A study of the impact of social media on consumers," International Journal of Market Research, vol. 56, pp. 95-113, 2014.

[3] Chen, L. and R. Wang, "Trust Development and Transfer from Electronic Commerce to Social Commerce: An Empirical Investigation," American Journal of Industrial and Business Management, vol. 6, pp. 568-576, 2016.

[4] Smith, C. (2016, 14 June 2016). By the numbers: 170+interesting Instagram Statitsics (April 2016). Available: http://expandedramblings.com/index.php/importantinstagram-stats/

[5] Moth, D. (2015, January 6). 20+ Instagram stats marketers need to know. Available:

https://econsultancy.com/blog/65939-20-instagram-statsmarketers-need-to-know

[6] Price, B. (2015, 14 June 2016). Infographic: Which social media platform drives the most sales? Available: http://www.demacmedia.com/infographic/social-mediadrives-sales/

[7] Lazazzera, R. (2014, 14 June 2016). How To Build A Massive Following On Instagram. Available:

https://www.shopify.com/blog/14288561-how-to-build-amassive-following-on-instagram

[8] Cheung, C. M., M. K. Lee, and N. Rabjohn, "The impact of electronic word-of-mouth: The adoption of online opinions in online customer communities," Internet Research, vol. 18, pp. 229-247, 2008.

[9] Sia, C. L., K. H. Lim, K. Leung, M. K. O. Lee, W. W. Huang, and I. Benbasat, "Web Strategies to Promote Internet Shopping: Is Cultural-Customization Needed?," MIS Quarterly, vol. 33, pp. 491-512, 2009.

[10] Lim, K. H., C. L. Sia, M. K. O. Lee, and I. Benbasat, "Do I trust you online, and if so, will I buy? An empirical study of two trust-building strategies," Journal of Management Information Systems, vol. 23, pp. 233-266, 2006.

[11] Palvia, P., "The role of trust in e-commerce relational exchange: A unified model," Information \& Management, vol. 46, pp. 213-220, 2009.

[12] McKnight, D. H., V. Choudhury, and C. Kacmar, "Developing and validating trust measures for e-commerce: An integrative typology," Information systems research, vol. 13, pp. 334-359, 2002.

[13] Yadav, M. S., K. d. Valck, T. Hennig-Thurau, D. L. Hoffman, and M. Spann, "Social commerce: a contingency framework for assessing marketing potential," Journal of Interactive Marketing, vol. 27, pp. 311-323, 2013.

[14] Cheung, C. M. and M. K. Lee, "Understanding consumer trust in Internet shopping: A multidisciplinary approach," Journal of the American society for Information Science and Technology, vol. 57, pp. 479-492, 2006.

[15] Schurr, P. H. and J. L. Ozanne, "Influences on Exchange Processes: Buyers Preconceptions of a Seller's Trustworthiness and Bargaining Toughness," Journal of Consumer Research, vol. 11, pp. 939-953, 1985.

[16] Doney, P. M. and J. P. Cannon, "An Examination of the Nature of Trust in Buyer-seller Relationships," Journal of Marketing, vol. 61, pp. 35-51, 1997.

[17] Dwyer, R. F., P. H. Schurr, and S. Oh, "Output Sector Munificence Effects on the Internal Political Economy of Marketing Channels," Journal of Marketing Research, vol. 24, pp. 347-358, 1987. 
[18] Das, T. K., "Between trust and control: Developing confidence in partner cooperation in alliances," The Academy of Management Review vol. 23, pp. 491-513, 1998.

[19] Moorman, C., R. Deshpande, and G. Zaltman, "Factors Affecting Trust in Market Research Relationships," Source: Journal of Marketing, vol. 57, pp. 81-101, 1993.

[20] Gefen, D. and D. W. Straub, "Gender differences in the perception and use of e-mail: An extension to the technology acceptance model," MIS quarterly, pp. 389-400, 1997.

[21] Jarvenpaa, S. L., N. Tractinsky, and M. Vitale, "Consumer trust in an internet store," Information Technology and Management, vol. 1, p. 45, 2000.

[22] Lee, M. K. O. and E. Turban, "Trust in business-toconsumer electronic commerce: A proposed research model and its empirical testing," Journal of Electronic Commerce, vol. 6, pp. 75-91, 2001.

[23] Lewicki, R. J. and B. B. Bunker, Trust in Relationships: A Model of Trust Development and Decline, Conflict, Cooperation, and Justice. San Francisco: JosseyBass, 1995.

[24] Mayer, R. C., J. H. Davis, and F. D. Schoorman, "An integrative model of organizational trust," Academy of management review, vol. 20, pp. 709-734, 1995.

[25] McKnight, H. D., V. Choudhury, and C. Kacmar, "Developing and Validating Trust Measures for eCommerce: An Integrative Typology," Information Systems Research, vol. 13, pp. 334-359, 2002.

[26] Rotter, J. B., "A new scale for the measurement of interpersonal trust1.Journal of personality," 35, vol. 4, 1967.

[27] Zucker, L. G., "Production of trust: Institutional sources of economic structure, 1840-1920," Research in Organizational Behavior, vol. 8, pp. 53-111, 1986.

[28] Fang, Y., I. Qureshi, H. Sun, P. McCole, E. Ramsey, and K. H. Lim, "Trust, Satisfaction, and Online Repurchase Intention: The Moderating Role of Perceived Effectiveness of E-Commerce Institutional Mechanisms," MIS Quarterly, vol. 38, pp. 407-427, 2014.

[29] McKnight, H. D., C. Kacmar, and V. Choudhury, "Shifting Factors and the Ineffectiveness of Third Party Assurance Seals: A Two-Stage Model of Initial Trust in a Web Business," Electronic Markets, vol. 14, pp. 252-266, 2004.
[30] Markus, M. L. and C. Soh, "Structural Influences on Global E-Commerce Activity," Journal of Global Information Management, vol. 10, pp. 5-12, 2002.

[31] Stewart, K. J., "Trust Transfer on the World Wide Web," Organization Science vol. 14, pp. 5-17, 2003.

[32] Childers, J. L., "Assessment of the psychometric properties of an opinion leader-ship scale," Journal of Marketing Research, vol. May, pp. 184-188, 1986.

[33] Egger, C., "Identifying Key Opinion Leaders in Social Network," Institute of Informatics, The University of Applied Sciences, 2016.

[34] Kelley, H. H., "The process of causal attribution," American Psychologist, vol. 28, pp. 107-128, 1973.

[35] Sia, C. L., K. H. Lim, K. Leung, M. K. Lee, W. W. Huang, and I. Benbasat, "Web strategies to promote internet shopping: is cultural-customization needed?," Mis Quarterly, pp. 491-512, 2009.

[36] McKnight, D. H., L. L. Cummings, and N. L. Chervany, "Initial trust formation in new organizational relationships," Academy of Management review,, vol. 23, pp. 473-490, 1998.

[37] Kramer, R. M., M. B. Brewer, and B. A. Hanna, "Collective trust and collective action," Trust in organizations: Frontiers of theory and research, pp. 357389, 1996.

[38] Herman, J. (2014, February 17). Instagram Statistics for 2014. Available: http://www.jennstrends.com/instagram-statistics-for-2014/

[39] Hair, J. F., W. C. Black, B. J. Babin, and R. E. Anderson, Multivariate Data Analysis, 7th Ed. Upper Saddle River: NJ: Prentice-Hall International, 2009.

[40] Wixom, B. H. and H. J. Watson, "An empirical investigation of the factors affecting data warehousing success," MIS Quarterly, vol. 25, pp. 17-41, 2001.

[41] Chin, W. W., "The Partial Least Square Approach to Structural Equation Modeling," in Modern Methods for Business Research, G. A. Marcoulides, Ed., ed Mahwah, NJ: Lawrence Erlbaum Associates, 1998, pp. 295-336.

[42] Karaiskos, D., E. Tzavellas, G. Balta, and T. Paparrigopoulos, "Social network addiction : a new clinical disorder?," European Psychiatry, vol. 25, p. 8552010.

[43] Fornell, C. and D. F. Larcker, "Evaluating structural equation models with unobservable variables and measurement error," Journal of marketing research, pp. 3950, 1981. 
[44] Koufaris, M. and W. Hampton-Sosa, "The development of initial trust in an online company by new customers," Information \&Management, vol. 41, pp. 377397, 2004.

[45] Podsakoff, P. M., S. B. MacKenzie, J.-Y. Lee, and N. P. Podsakoff, "Common method biases in behavioral research: a critical review of the literature and recommended remedies," Journal of Applied Psychology, vol. 88, 2003.

[46] Harman, H. H., Modern factor analysis. Chicago: University of Chicago Press, 1967.

[47] Podsakoff, P. M. and D. W. Organ, "Self-reports in organizational research - problems and prospects," Journal of Management, vol. 12, pp. 531-544, 1986.

\section{Appendix A}

Table A1. Measurement items

\begin{tabular}{|c|c|c|}
\hline Construct & Items & Source \\
\hline \multirow{4}{*}{$\begin{array}{l}\text { Purchase } \\
\text { Intention } \\
\text { (PIT) }\end{array}$} & $\begin{array}{l}\text { I am considering purchasing } \\
\text { from Instagram now. }\end{array}$ & \multirow[b]{4}{*}{ [46] } \\
\hline & $\begin{array}{l}\text { I would seriously contemplate } \\
\text { buying from Instagram. }\end{array}$ & \\
\hline & $\begin{array}{l}\text { I am likely to make future } \\
\text { purchases from this site. }\end{array}$ & \\
\hline & $\begin{array}{l}\text { I am likely to make future } \\
\text { purchases from this site. }\end{array}$ & \\
\hline \multirow[b]{6}{*}{$\begin{array}{l}\text { Peer } \\
\text { customer } \\
\text { endorsement } \\
\text { (CE) }\end{array}$} & $\begin{array}{l}\text { Instagram web site displays } \\
\text { testimonials from satisfied } \\
\text { customers. }\end{array}$ & \multirow[b]{6}{*}[30,45]{} \\
\hline & $\begin{array}{l}\text { I can see from the comments in } \\
\text { Instagram store that existing } \\
\text { customers are satisfied with the } \\
\text { Instagram store. }\end{array}$ & \\
\hline & $\begin{array}{l}\text { I believe customer } \\
\text { recommendation from } \\
\text { Instagram to be true. }\end{array}$ & \\
\hline & $\begin{array}{l}\text { Customer feedback in } \\
\text { Instagram store will improve my } \\
\text { online shopping performance. }\end{array}$ & \\
\hline & $\begin{array}{l}\text { Customer feedback in } \\
\text { Instagram store will enhance my } \\
\text { shopping effectiveness. }\end{array}$ & \\
\hline & $\begin{array}{l}\text { Customer feedback in } \\
\text { Instagram store will increase my } \\
\text { productivity when shopping } \\
\text { online. }\end{array}$ & \\
\hline \multirow[b]{3}{*}{$\begin{array}{l}\text { Peer opinion } \\
\text { leader } \\
\text { endorsement } \\
(\mathrm{KOL})\end{array}$} & $\begin{array}{l}\text { There are many reputable third } \\
\text { party certification bodies (for } \\
\text { example, Celebrities, Key } \\
\text { Option Leader available for } \\
\text { assuring the trustworthiness of } \\
\text { Internet vendors. }\end{array}$ & \\
\hline & $\begin{array}{l}\text { I think third party recognition } \\
\text { bodies are doing a good job. }\end{array}$ & \\
\hline & $\begin{array}{l}\text { Existing third-party recognition } \\
\text { bodies are adequate for the } \\
\text { protection of Internet shopper } \\
\text { interest. }\end{array}$ & [8] \\
\hline
\end{tabular}

\begin{tabular}{|c|c|c|}
\hline & $\begin{array}{l}\text { You will closely followed the } \\
\text { suggestions from reputable third } \\
\text { party certification bodies and } \\
\text { went to the recommended } \\
\text { Instagram store. }\end{array}$ & \\
\hline \multirow[b]{2}{*}{$\begin{array}{l}\text { Perceived } \\
\text { benevolence } \\
\text { (PB) }\end{array}$} & $\begin{array}{l}\text { I believe that Instagram vendor } \\
\text { would act in my best interest. }\end{array}$ & \multirow[b]{2}{*}{ [45] } \\
\hline & $\begin{array}{l}\text { If I required help, Instagram } \\
\text { vendor would do it best to help } \\
\text { me. }\end{array}$ & \\
\hline \multirow[b]{3}{*}{$\begin{array}{l}\text { Perceived } \\
\text { Competence } \\
\text { (PC) }\end{array}$} & $\begin{array}{l}\text { Instagram vendors have the } \\
\text { ability to handle sales } \\
\text { transactions on the Instagram. }\end{array}$ & \multirow[b]{3}{*}{ [8] } \\
\hline & $\begin{array}{l}\text { Instagram vendors have } \\
\text { sufficient expertise and } \\
\text { resources to do business on the } \\
\text { Internet. }\end{array}$ & \\
\hline & $\begin{array}{l}\text { Instagram vendors have } \\
\text { adequate knowledge to manage } \\
\text { their business on the Instagram. }\end{array}$ & \\
\hline \multirow[b]{3}{*}{$\begin{array}{l}\text { Perceived } \\
\text { Integrity (PI) }\end{array}$} & $\begin{array}{l}\text { Instagram vendors will not } \\
\text { charge Instagram shoppers } \\
\text { more for Instagram shopping. }\end{array}$ & \multirow[b]{3}{*}{ [8] } \\
\hline & $\begin{array}{l}\text { Instagram vendors are honest to } \\
\text { their consumers. }\end{array}$ & \\
\hline & $\begin{array}{l}\text { Instagram vendors act sincerely } \\
\text { in dealing with customers. }\end{array}$ & \\
\hline \multirow[b]{2}{*}{$\begin{array}{l}\text { Propensity to } \\
\text { Trust [44] }\end{array}$} & $\begin{array}{l}\text { My tendency to trust a } \\
\text { person/thing is high. }\end{array}$ & \multirow[b]{2}{*}{ [8] } \\
\hline & $\begin{array}{l}\text { I tend to trust a person/thing, } \\
\text { even though I have little } \\
\text { knowledge of it. }\end{array}$ & \\
\hline \multirow[b]{5}{*}{$\begin{array}{l}\text { Consumer } \\
\text { Trust (TR) }\end{array}$} & $\begin{array}{l}\text { I trust Instagram vendors keep } \\
\text { customers the best interests in } \\
\text { mind. }\end{array}$ & \multirow[b]{5}{*}{30,45} \\
\hline & $\begin{array}{l}\text { Instagram shopping is } \\
\text { trustworthy. }\end{array}$ & \\
\hline & $\begin{array}{l}\text { I think that Instagram vendors } \\
\text { will not do anything to take } \\
\text { advantage of its customers. }\end{array}$ & \\
\hline & $\begin{array}{l}\text { I believe that the Instagram } \\
\text { stores I visit keep its promises } \\
\text { and commitments. }\end{array}$ & \\
\hline & $\begin{array}{l}\text { I trust information on Instagram } \\
\text { to be true. }\end{array}$ & \\
\hline
\end{tabular}

